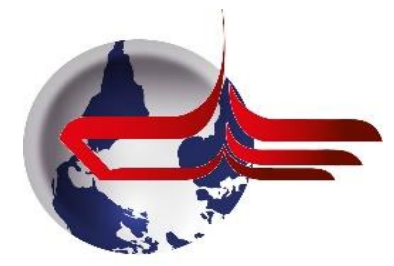

Turkish Journal of Educational Studies, 6 (3) Ekim 2019

Research Article / Araştırma Makalesi

Received/Geliş: 06.08. 2019 Accepted/Kabul: 07.10.2019 Published/Yayınlanma: 25.10.2019

\title{
Ortaokul Öğrencilerinin Geometri Öz-Yeterlik İnançlarının ve Geometrik Düşünme Becerilerinin İncelenmesi ${ }^{1}$
}

\author{
Hasan Güner BERKANT ${ }^{1}$
}

Gökhan ÇADIRLI²

\section{$\ddot{O} \mathbf{z}$}

Bu çalışmanın genel amacı, ortaokul öğrencilerinin geometrik düşünme becerileri ile geometriye yönelik özyeterlik inançlarının bazı değişkenlere göre incelenmesidir. Araştırma tarama modelinde gerçekleştirilmiştir. Araştırmanın evrenini Kahramanmaraş ilinin Onikişubat ve Dulkadiroğlu ilçelerinde öğrenim gören ortaokul öğrencileri oluşturmaktadır. Araştırmanın örneklemi ise bu ilçelerin beş farklı ortaokulunda öğrenim gören öğrencilerden oluşmaktadır. Araştırmanın verileri "Van Hiele Geometrik Düşünme Düzey Belirleme Testi" ve "Geometriye Yönelik Öz-yeterlik İnançları Ölçeği”" ile toplanmıştır. Araştırmada elde edilen sonuçlardan bazıları şunlardır: Ortaokul öğrencilerinin yarıdan fazlasının geometrik düşünme düzeylerinin olması gereken düzeyin altında yer aldığı, öğrencilerin geometrik düşünme düzeylerinin cinsiyet değişkeni ve okul öncesi eğitim durumlarına göre değişmediği, sekizinci sınıf öğrencilerinin geometrik düşünme düzeylerinin yedinci sınıf öğrencilerinin geometrik düşünme düzeylerinden daha yüksek olduğu, anne ve baba eğitim seviyesi yükseldikçe öğrencilerin geometrik düşünme düzeylerinin de yükseldiği sonuçlarına varılmıştır. Öğrencilerin geometriye yönelik öz-yeterlik inanç puanlarının aritmetik ortalamanın üzerinde olduğu, cinsiyet değişkeninin öğrencilerin geometriye yönelik öz-yeterlik inançlarını etkilemediği, yedinci sınıf öğrencilerinin, okul öncesi eğitim alan öğrencilerin ve anne baba eğitim durumu yüksek olan öğrencilerin geometriye yönelik öz-yeterlik inançlarının daha yüksek olduğu sonuçlarına varılmıştır. Ayrıca öğrencilerin geometrik düşünme düzeyleri ile geometriye yönelik öz-yeterlik inançları arasında düşük düzeyde pozitif yönlü anlamlı bir ilişki olduğu sonucuna varılmıştır.

Anahtar Kelimeler: Matematik ögretimi, geometri ögrretimi, geometrik düşünme becerisi, geometri öz-yeterlik inancl, ortaokul ögrencileri

\section{An Analysis of Secondary School Students' Geometry Self-Efficacy Beliefs and Their Geometric Thinking Skills}

\begin{abstract}
This study aims at analysing the secondary school students' self-efficacy beliefs towards geometry alongside their geometric thinking skills according to some variables. The study has been carried out in a survey model. The population includes students attending to secondary schools of Onikişubat and Dulkadiroğlu sub-provinces in

\footnotetext{
1 Bu çalışma, Gökhan Çadırlı’nın (2017) Kahramanmaraş Sütçü İmam Üniversitesi Sosyal Bilimler Enstitütüsü’nde tamamladığ 1 yüksek lisans tezinden üretilmiş olup, ICOESS (2018)'de sözlü bildiri olarak sunulmuştur.

${ }^{1}$ Prof.Dr., Yozgat Bozok Üniversitesi Eğitim Fakültesi Eğitim Bilimleri Bölümü, hgberkant@gmail.com

${ }^{2}$ Matematik Öğretmeni, Rabia Arıkan İmam Hatip Ortaokulu, Kahramanmaraş, cadirli gokhan@hotmail.com
} 
Kahramanmaraş city. The sample consists of students studying at five different secondary schools in the aforementioned sub-provinces. The data of this research has been collected through Van Hiele Geometric Thinking Test and Self-Efficacy Scale toward Geometry. Some research results are as follows: the geometrical thinking levels of more than half of the secondary school students are below the acceptable level, the geometrical thinking levels of the students do not differ by their gender and pre-school conditions, the geometrical thinking levels of eighth grade students are higher than that of seventh grade students and the higher the educational levels of parents climb, the higher the geometrical thinking levels of students reach. It has been concluded that students' selfefficacy beliefs towards geometry are above average, gender as a variety does not affect the self-efficacy beliefs of the students towards geometry and the students who are seventh grades, have taken pre-school education and have parents with high educational levels have a higher level of self-efficacy belief towards geometry. Moreover, it has been deduced that there is a low-level positive and meaningful relation between the geometrical thinking levels of the students and the self-efficacy beliefs towards geometry.

Keywords: Mathematics education, geometry education, the skill of geometric thinking, geometry self-efficacy beliefs, secondary school students

\section{Giriş}

Geometri, içinde yaşadığımız fiziksel dünyayı şekil, yer ve konum açısından inceleme imkânı verir. Yaşamın hemen her noktasında yeri bulunan geometrik şekillerin özelliklerinin öğrenciler tarafından öğrenimi belirli bir sistematiğe göre gerçekleşir (Develi ve Orbay, 2003; Olkun ve TolukUçar, 2006). Bu sistematik süreç, öğrencilerin geometrik düşünme becerilerini gerektirmektedir. Özellikle son yüz yıl içinde geometriyi öğretme ve öğrenme süreçlerinin etkili olmasına yönelik birçok araştırma yapılmış ve geometrik düşünmenin doğası ve geliştirilebilme yolları açıklanmaya çalışılmıştır (Güven ve Karpuz, 2016). Geometrinin somut şekillerle ilgilenmesi ve matematik öğrenmeyi kolaylaştırması sebebiyle erken yaşlarda öğretilmesi gerekmektedir. Ayrıca geometrinin müstakil ders olarak değil de matematiğin diğer dalları ile bütünleşik olarak verilmesi ve bunu yaparken de çocukta geometrik düşüncenin nasıl geliştiğinin bilinmesi gerekmektedir (Olkun ve Toluk-Uçar, 2014).

Geometrik düşünme üzerine çalışmalar yapan Hollandalı eğitimciler Pierre ve Dina Van Hiele Geldof, lise geometrisinde bazı öğrencilerin başarılı bazılarının ise başarısız olduğunu gözlemlemiş ve bunun nedenleri üzerine araştırma yapmışlardır (Baki, 2006). Bu araştırma geometrik düşünmenin beş basamakta olabileceğini göstermiştir (Altun, 2015a; Baykul, 2016). Bu beş düzey ayrı ayrı geometrik düşünme süreçlerini açıklamaktadır. Düzeyler, öğrencilerin sahip olması gereken bilgilerin ne kadar olması gerektiğinden ziyade, öğrencilerin üzerinde düşünebileceği farklı geometrik fikirlerin ne olduğu ve nasıl düşündüklerini tanımlamaktadır (Van de Walle ve diğerleri, 2013). Van Hieleler geometrik düşünmenin gelişiminin beş basamaktan oluştuğunu önermiş ve bunları $0,1,2,3$ ve 4 . düzey olarak adlandırmışlardır (Altun, 2015b; Baykul, 2014; Van Hiele, 1986). Ancak daha sonra yapılan bazı çalışmalarda düzeyler 1, 2, 3, 4 ve 5 olarak ifade edilmiştir (Duatepe-Paksu, 2016; Hoffer, 1981). Clements ve Batista (1992) Van Hiele’nin beş düzeyinden önce biliş-öncesi (precognition) düzeyin 
olduğunu ileri sürmüşler ve daha sonra yaptıkları çalışmada bunu ispatlamışlardır (Aslan ve Aktaş Arnas, 2005). Bu nedenle bu çalışmada düzeyler 1, 2, 3, 4 ve 5 olarak adlandırılımıştır. Bu düzeylere ek olarak biliş-öncesi düzeye de yer verilmiştir.

Biliş̧ öncesi (Düzey 0) düşünme düzeyinin varlığı bazı araştırmacılar tarafından tartışmalı olmasına rağmen, bu düzeyin kabul edildiği çalışmalar da bulunmaktadır (Halat, 2006: 273). Bu düzeyde çocuklar geometrik şekilleri algılayabilirler, ancak algısal yetersizliklerinden dolayı şekillerin görsel özelliklerinden bazılarını ayırt edemeyebilirler (Clements ve Batista, 1992). Bu düzeydeki öğrencilere okul öncesinde, birinci sınıfta ve özel eğitim sınıflarında rastlanabilir (Halat, 2006).

Görsel (Düzey 1) düzeydeki bir öğrenci geometrik şekilleri açı, kenar, köşe gibi özellikleri parça yerine bir bütün olarak algılamaktadır (Baykul, 2016; Olkun ve Toluk-Uçar, 2006: 98). Bu evredeki çocuklara geometri öğretiminde fiziksel araç-gereçlerin sunulması, çocukların bunlarla oynaması ve kullanması gerekmektedir (Altun, 2015b).

Analiz (Düzey 2) düzeyi öğrencilerin, geometrik şekillerin parçalardan oluştuğunu ve bu parçaların bazı özelliklere sahip olduğunu fark edebildikleri bir düzeydir (Duatepe-Paksu, 2016). Bu düzeydeki çocuklar geometrik şekillerin yapılarını analiz edebilirler ve bunları açıklayabilirler (Altun, 2015b: 346). İlkokulların 4. ve 5. sınıf öğrencileri bu düzeyde yer almaktadırlar (Altun, 2015a).

İnformel çıkarım düzeyinde (Düzey 3) bir öğrenci bir sınıftaki şekiller ve sınıfların özellikleri arasında ilişki kurabilir, takip edebilir ve anlayabilirler (Baykul, 2016; Van de Walle ve diğerleri, 2013). $\mathrm{Bu}$ düzeyde çocuklar özelliği veya ayrıtı bütünden bağımsız olarak düşünebilmektedirler (Altun, 2015b). İlköğretimin ikinci kademesi çoğunlukla bu basamağa denk gelmektedir.

Formel çıkarım düzeyinde (Düzey 4) öğrenciler bir matematiksel sistem içerisinde akı1 yürütebilmekte, tanım ve teoremlere dayalı olarak ispat yapabilmektedirler (Duatepe-Paksu, 2016; Olkun ve Toluk-Uçar, 2006). Bu seviyedeki bir çocuk için şekillerin özellikleri şekil ve cisimlerden bağımsız hale gelir. Bu düzey lise dönemine karşılık gelmektedir (Altun, 2015b:347).

En üst düzey (Düzey 5) matematikle bir bilim olarak ilgilenenlerin ulaştığı bir düzeydir ve öğrenciler bu düzeyde bir matematikçi gibi geometri çalışabilirler (Duatepe-Paksu, 2016). Öğrenciler böylece geometriyi bir bilim dalı olarak algılayıp çalışabilirler (Altun, 2015b; Baykul, 2016).

Geometrik düşünmenin üst düzeylerine ulaşmada, öğrencilerin duyuşsal özelliklerinin de önemli etkenler arasında yer aldığı düşünülmektedir. Önemli duyuşsal özelliklerden biri olan öz-yeterlik, Bandura'nın davranışlar üzerinde etkili olduğunu düşündüğü temel kavramlardan biridir (Senemoğlu, 1997). Bandura (1997) öz-yeterliği, "bireyin belli bir performansı göstermek için gerekli etkinlikleri organize edip başarılı olarak sergileme kapasitesi ile ilgili olarak kendine ilişkin yargısı" şeklinde tanımlamıştır. Sosyal bilişsel kuramcılara göre öz-yeterlik inancı, bireysel tercihleri, bir iş için gösterilen 
çabayı ve yaşadıkları endişeyi anlamlı biçimde etkilemektedir (Işsksal ve Aşkar, 2003). Bu bağlamda öğrencilerin matematik öz-yeterlik inancının da matematik öğrenme süreçlerinde önemli olduğu varsayılmaktadır. Matematik öz-yeterlik inancı, bir bireyin belirli bir sorunu veya problemi tam olarak yerine getirme veya gerçekleştirme yeteneğine olan güvenine ilişkin durumsal veya probleme özgü bir değerlendirme (Hackett ve Betz, 1989) olarak tanımlanmaktadır. Bir durumla ilgili öz-yeterlik inançları yüksek olan bireylerin, bir işin üstesinden gelmek için çok çaba gösterdikleri, olumsuz bir durumla karşılaştıklarında kolayca pes etmedikleri, kararlı ve sabırlı oldukları düşünüldügünnde (Aşkar ve Umay, 2001), öğrencilerin matematiğin bir dalı olan geometri öz-yeterlik inançlarının da geometri öğrenme ve geometrik düşünmede etkili olabileceği ileri sürülebilir.

İlgili alanyazın incelendiğinde Usiskin (1982), Senk (1989), Cantürk-Günhan (2006), Idris (2009), Fidan ve Türnüklü (2010) ve Alaylı (2012), ortaokul öğrencilerinin geometrik düşünme düzeylerinin olması gereken seviyede bulunmadığı sonucuna ulaşmışlardır. Gül (2014), ortaokul sekizinci sınıf öğrencilerinin Van Hiele geometrik düşünme düzeylerine göre düzey 1 ve daha alt düzeylerde olduğunu, cinsiyet değişkeninin öğrencilerin geometrik düşünme düzeylerini etkilemediğini saptamışlardır. Karakarçayıldız (2016), ortaokul yedinci sınıf öğrencilerinin geometrik düşünme seviyelerinin düşük olduğunu ve öğrencilerin geometrik düşünme düzey belirleme testi ağırlıklı puanlarının cinsiyet, okul öncesi eğitim durumu, anne ve baba öğrenim durumu değişkenlere göre farklılaşmadığı sonucuna ulaşmıştır.

Erkek ve Işıksal-Bostan (2015), sekizinci sınıf öğrencilerinin geometriye yönelik öz-yeterlik inançlarının orta düzeyde olduğu sonucuna ulaşmışlardır. Işıksal ve Aşkar (2003), Chen ve Zimmerman (2007), Ayotola ve Adedeji (2009), Çetin (2009), Özkan (2010), Uzar (2010), Erdoğan, Baloğlu ve Kesici (2011), Çağırgan-Gülten ve Soytürk (2013), Yıldırım ve Özkan (2013), Erkek ve Işsıksal-Bostan (2015), cinsiyet değişkeninin öğrencilerin matematik öz-yeterlik inançlarını etkilemediğini belirlemişlerdir. Işıksal ve Aşkar (2003), Chen ve Zimmerman (2007) ve Ayotola ve Adedeji (2009), Uzar (2010), Erdoğan, Baloğlu ve Kesici (2011), Çağırgan-Gülten ve Soytürk (2013) öğrencilerin matematik öz-yeterlik inançları ile matematik başarıları arasında pozitif yönde bir ilişki olduğu sonucuna ulaşmışlardır. Çetin (2009) öğrencilerin öz-yeterlik inançlarının anne-baba eğitim durumuna göre anlamlı bir farklılık göstermediği, Yıldırım ve Özkan (2013) ise anne-baba eğitim seviyesinin öğrencilerin geometriye yönelik öz-yeterlik inançlarını olumlu yönde etkilediği sonuçlarına ulaşmışlardır. Çetin (2009), öğrencilerin öz-yeterlik inançlarının okul türüne göre anlamlı biçimde değişmediğini, Özkan (2010) sınıf seviyesi arttıkça öğrencilerin geometriye yönelik olumlu öz-yeterlik inançlarının azalabileceği sonuçlarına ulaşırken, Uzar (2010) ise sınıf seviyesi değişkeninin öğrencilerin matematik öz-yeterlik inançlarını etkilemediği sonucuna ulaşmıştır. Yenilmez ve Korkmaz (2013), geometriye yönelik öz-yeterliğin öğrencilerin okul öncesi eğitim alma durumlarına göre 
farklılaşmadığını, geometriye yönelik öz-yeterlik ile geometrik düşünme düzeyi arasında anlamlı ve pozitif yönde ancak düşük düzeyde bir ilişkinin bulunduğunu belirlemişlerdir. Yılmaz (2011), Kaba, Boğazlıyan ve Daymaz (2016), ortaokul öğrencilerinin matematik dersine yönelik tutumları ile matematik öz-yeterlik inançları arasında da pozitif ve yüksek düzeyde anlamlı bir ilişki olduğunu belirlemişlerdir.

Yukarıda değinilen araştırmalarda ayrı ayrı incelenen öğrencilerin geometrik düşünme becerileri ve geometriye yönelik öz-yeterlik inançları, bu çalışmada beraberce ve bazı değişkenler açısından incelenmiş, ayrıca bu iki bağımlı değişken arasındaki ilişki de belirlenmeye çalışılmıştır. Türk öğrencilerin gerek ulusal gerekse uluslararası sınavlarda matematik başarısının düşük olduğu, matematik içerisinde de geometri dersinde öğrencilerin daha çok zorlandıkları görülmektedir. Öğrencilerin geometri başarısını artırmak ve onların matematiğe yönelik tutumlarını olumlu yönde değiştirmek için onların bulundukları seviyenin belirlenip, buna göre öğretim yapmanın önemli olduğu düşünülmektedir. Öğrencilerin geometrik düşünme düzeylerini belirlemede Van Hiele kuramının önemli bir yeri olduğu yapılan çalışmalarda ortaya konmuştur (Napitipulu, 2004; Pusey, 2003). Ayrıca Akkaya da (2006) Van Hiele kuramına göre tasarlanmış geometri öğretiminin öğrencilerin geometrik düşünme düzeylerini, geometri başarılarını ve geometri dersine yönelik tutumlarını geliştirdiğini tespit etmiştir. Bu bağlamda araştırmada, öğrencilerin geometrik düşünme becerilerinin ve geometriye yönelik öz-yeterlik algılarının çeşitli değişkenlere göre incelenmesinin alana katkı sağlayacağı düşünülmektedir. Buna göre çalışmanın problem cümlesi, "Ortaokul öğrencilerinin geometrik düşünme becerilerinin ve geometriye yönelik öz-yeterlik inançlarının çeşitli değişkenlerle ve birbirleriyle olan ilişkisi nedir?" şeklinde ifade edilebilir.

\subsection{Araştırmanın Amacı}

Bu çalışmanın genel amacı, ortaokul öğrencilerinin geometrik düşünme becerileri ile geometriye yönelik öz-yeterlik inançlarının bazı değişkenlere göre incelenmesidir. Bu genel amaç kapsamında aşağıdaki sorulara cevap aranmıştır:

1. Ortaokul öğrencilerinin geometrik düşünme düzeyleri nedir?

2. Ortaokul öğrencilerinin geometrik düşünme düzey testinde aldıkları ağırlıklı puanları nedir?

3. Ortaokul öğrencilerinin geometrik düşünme ağırlıklı puanları

a. Sinıf düzeylerine göre,

b. Anne ve babalarının öğrenim düzeylerine göre,

c. Cinsiyetlerine göre,

d. Okul öncesi eğitim alma durumlarına göre anlamlı bir şekilde farklılaşmakta mıdır? 
4. Ortaokul öğrencilerinin geometriye yönelik öz-yeterlik inançlarının düzeyi nedir?

5.Ortaokul öğrencilerinin geometriye yönelik öz-yeterlik inançları;

a. Sinıf düzeylerine göre,

b. Anne ve babalarının öğrenim düzeylerine göre,

c. Cinsiyetlerine göre,

d. Okul öncesi eğitim alma durumlarına göre, anlamlı bir şekilde farklılaşmakta mıdır?

6. Öğrencilerin geometrik düşünme becerileri ile geometriye yönelik öz-yeterlik inançlanı arasında anlamlı bir ilişki var mıdır?

\section{Yöntem}

\subsection{Araştırmanın Modeli}

Ortaokul öğrencilerinin geometrik düşünme becerileri ile geometriye yönelik öz-yeterlik inançlarını incelemeyi amaçlayan bu araştırma ilişkisel tarama modelinde betimsel bir çalışmadır. İlişkisel tarama modeli iki ya da daha çok değişken arasındaki birlikte değişimin varlığını veya derecesini belirlemeyi amaçlayan araştırma modelleridir (Karasar, 2007: 81). Çalışmada öğrencilerin geometrik düşünme becerileri ve geometriye yönelik öz-yeterlik inançları bağımlı değişkenleri oluştururken, öğrencilerin sınıf düzeyi, anne-baba öğrenim düzeyleri, cinsiyetleri ve okul öncesi eğitim alma durumları bağımsız değişkenleri oluşturmaktadır.

\subsection{Evren ve Örneklem}

Araştırmanın evrenini Kahramanmaraş ilinin Dulkadiroğlu ve Onikişubat ilçelerinde öğrenim gören yedinci ve sekizinci sınıf öğrencileri oluşturmaktadır. Evrenin bu iki ilçe olarak belirlenmesinde merkez ilçe olmaları dikkate alınmıştır. Araştırmanın örneklemini ise bu evrenden kolay ulaşılabilir örneklem yoluyla belirlenmiş olan 505 ortaokul öğrencisi oluşturmaktadır. Öğrencilerin öğrenim gördükleri okullar seçilirken düşük, orta ve yüksek sosyo-ekonomik çevrelerde olmasına dikkat edilmiştir. Öğrencilerin 274'ü (\%54.3) kız, 231’i (\%45.7) erkek, 241’i (\%47.7) yedinci sınıfta, 264’ü (\%52.3) sekizinci sınıfta öğrenim görmektedir. Kolay ulaşılabilir örneklem, araştırmacının veriyi toplarken zaman, ulaşılabilirlik, kolaylık gibi avantajlara sahip olduğu durumlar için geçerlidir (Yıldırım ve Şimşek, 2018). Bu çalışmada araştırmacılar örnekleme ulaşırken meslektaşlarından veri toplamada yardım aldıklarından dolayı araştırmada kolay ulaşılabilir örneklem kullanılmıştır. 


\subsection{Veri Toplama Araçları}

Ortaokul öğrencilerinin geometrik düşünme becerileri ile geometriye yönelik öz-yeterlik inançlarının incelenmesini amaçlayan bu araştırmada veri toplama aracı olarak kişisel bilgi formu, Van Hiele Geometrik Düşünme Düzey Belirleme Testi ve Geometriye Yönelik Öz Yeterlik Ölçeği kullanılmıştır.

Van Hiele Geometrik Düşünme Düzey Belirleme Testi, öğrencilerin geometrik düşünme düzeylerini belirlemek için Özcan (2012) tarafından geliştirilmiştir. Özcan (2012) hazırlanan testin kapsam geçerliğini belirlemek için Van Hiele geometrik düşünme düzeyleri ile ilgili çalışmalar taramış, konu ile ilgili bilgisi olan öğretim üyelerinden ve öğretmenlerden uzman görüşü almıştır. Testte yer alan maddelerin öğrenciler açısından anlaşılır olup olmadığını saptamak için test maddeleri üç öğrenciye vermiş ve maddelerde anlaşılmayan yerler olup olmadığı sorulmuş ve öğrencilerden alınan geri bildirimler doğrultusunda bazı düzeltmeler yapmıştır. Daha sonra bu testin yedinci sınıfta öğrenim gören 100 öğrenci, sekizinci sınıfta öğrenim gören 93 öğrenci ve lisede öğrenim gören 33 öğrenci olmak üzere toplamda 216 öğrenciyle pilot çalışmasını yapmıştır. Geliştirilen test 30 maddeden ve 4 farklı düzeyden oluşmaktadır. Testin aritmetik ortalamasını 30.44, güvenirlik katsayısını .89 , ortalama güçlügünü ise .56 olarak hesaplamıştır. Maddelerin düzeylere göre dağılımı Tablo 1'de verilmiştir.

Tablo 1. Geometrik Düşünme Düzey Belirleme Testi Sorularının Düzeylere Göre Dağılımı

\begin{tabular}{lc}
\hline Düzey & Soru Sayısı \\
\hline 1.düzey & 5 \\
2.düzey & 10 \\
3.düzey & 10 \\
4.düzey & 5 \\
\hline
\end{tabular}

Tablo 1 incelendiğinde birinci ve dördüncü düzeylerde 5'er, ikinci ve üçüncü düzeylerde 10'ar madde olduğu görülmektedir. Geometrik düşünme düzey belirleme testi değerlendirme ölçütleri aşağıda verilmiştir:

-1. düzey sorularından $3 ; 2$. ve 3 . düzey sorularından $6 ; 4$. düzey sorularından 3 ya da daha fazla soruya doğru yanıt vermeyen öğrenciye 0 ,

- 1. düzey sorulardan 3 ya da daha fazla soruya doğru yanıt veren öğrenciye 1 ,

-2. düzey sorulardan 6 ya da daha fazla soruya doğru yanıt veren öğrenciye 2,

-3. düzey sorulardan 6 ya da daha fazla soruya doğru yanıt veren öğrenciye 4 ,

-4. düzey sorulardan 3 ya da daha fazla soruya doğru yanıt veren öğrenciye 8 puan verilir.

- Öğrencilerin 1. düzeye atanması için 5 sorudan en az 3'ünü doğru yanitlaması gerekmektedir. 
- Öğrencilerin 2. düzeye atanması için 1. düzeyle ilgili sorulardan en az 3 ve 2. düzey sorulardan en az 6'sını doğru yanıtlaması gerekmektedir.

- Öğrencilerin 3. düzeye atanması için 1. düzey sorulardan en az 3, 2 ve 3. düzey sorulardan en az 6'sını doğru yanıtlaması gerekmektedir.

Öğrencilerin 4. düzeye atanması için 1. düzeyden en az 3, 2 ve 3. düzeyden en az 6 ve 4. düzeyden en az 3 soruyu doğru yanıtlaması gerekmektedir. Verilen bu değerlendirme ölçütlerinden hareketle öğrencilerin kaç puanla hangi düzeyde yer alacağ Tablo 2'de verilmiştir. Tablo 2 incelendiğinde bir öğrencinin herhangi bir düzeye atanabilmesi için geometrik düşünme testinden alması gereken en az puan görülmektedir. Puanlar birikimli olarak düzeylere karşılık geldiğinden, düzeyler arasındaki puan farkı bu nedenle ortaya çıkmaktadır.

Tablo 2. Van Hiele Geometrik Düşünme Düzeylerine Ait Ağırlıklı Puanlar

\begin{tabular}{ll}
\hline Düzey & Puan \\
\hline 1.Düzey & 1 \\
2.Düzey & 3 \\
3.Düzey & 7 \\
4.Düzey & 15 \\
5.Düzey & 31 \\
\hline
\end{tabular}

Geometriye Yönelik Öz-Yeterlik Ölçeği, Başer ve Cantürk-Günhan (2007) tarafından geliştirilmiştir. Ölçek 25 maddeden oluşmakta olup, "Hiçbir zaman, Ara sıra, Kararsızım, Çoğu zaman, Her zaman” şeklinde derecelendirilmiştir. Ölçeğin güvenirlik katsayıları Tablo 3'te verilmiştir. Tablo 3’te görüldüğü gibi ölçeğin genelinin ve alt boyutlarının hem bu çalışmada hem de geliştirme çalışmasında yeterli düzeyde güvenilir olduğu görülmektedir.

Tablo 3. Geometriye Yönelik Öz-Yeterlik Ölçeğinin Alt Boyutlarında ve Genelinde Cronbach Alfa Güvenirlik

\begin{tabular}{|c|c|c|c|}
\hline \multicolumn{4}{|c|}{ Katsayıları } \\
\hline Alt Boyutlar & $\begin{array}{l}\text { Madde } \\
\text { Sayıları }\end{array}$ & $\begin{array}{l}\text { Cronbach } \\
\text { Alpha } \\
\text { Güvenirlik } \\
\text { Katsayısı }\end{array}$ & $\begin{array}{c}\text { Bu çalışmada elde edilen } \\
\text { Cronbach Alpha } \\
\text { Güvenirlik Katsayısı }\end{array}$ \\
\hline $\begin{array}{l}\text { Olumlu öz-yeterlik } \\
\text { inancı }\end{array}$ & 12 & .88 & .87 \\
\hline $\begin{array}{l}\text { Geometri bilgisinin } \\
\text { kullanılması }\end{array}$ & 6 & .70 & .71 \\
\hline $\begin{array}{l}\text { Olumsuz öz-yeterlik } \\
\text { inancı }\end{array}$ & 7 & .70 & .73 \\
\hline Genel & 25 & .90 & .89 \\
\hline
\end{tabular}




\subsection{Verilerin Toplanması ve Analizi}

Veri toplama araçları araştırmacıların gözetiminde örneklemdeki öğrencilere öğrenim gördükleri okulda ders saatleri içinde uygulanmıştır. Toplanan veriler üzerinde betimsel istatistikler, bağımsız gruplar t-testi, tek faktörlü varyans analizi (ANOVA), LSD testi, Mann-Whitney U testi, Kruskal-Wallis $\mathrm{H}$ testi ve Pearson korelasyon analizi uygulanmıştır. Verilerin analizinde testlere karar verilirken Levene testi sonuçları dikkate alınmıştır. Varyansların homojen olduğu durumlarda parametrik, homojen olmadığı durumlarda ise non-parametrik testler uygulanmıştır. Geometriye yönelik öz-yeterlik ölçeği üç alt boyuttan oluşmasına karşın olumlu ve olumsuz öz-yeterlik inancı alt boyutlarının aynı özelliği ölçtükleri görüldüğünden bu iki alt boyut birleştirilip tek boyut olarak alınmış ve analizlere bu şekilde devam edilmiştir. Analiz sonuçlarından elde edilen anlamlı farklılıkların etki büyüklükleri hesaplanmıştır. Etki büyüklüğü, bağımsız değişkenin bağımlı değişken üzerinde ne derece etkili olduğunu gösterir ve 0.00 ile 1.00 arasında değişir. Etki büyüklüğü .01, .06 ve .14 olması sirasıyla küçük, orta ve geniş etki büyüklügü olarak yorumlanır (Büyüköztürk, 2007; Büyüköztürk, Çokluk ve Köklü, 2015).

\section{Bulgular}

Ortaokul öğrencilerinin geometrik düşünme düzey testine göre düzeylerine ait betimsel istatistikler Tablo 4'te verilmiştir. Tablo 4 incelendiğinde öğrencilerin çoğunluğunun geometrik düşünme düzeylerinin birinci ve ikinci düzeyinde olduğu, az sayıda öğrencinin de sıfirıncı ve dördüncü düzeylerde yer aldığı görülmektedir.

Tablo 4. Ortaokul Öğrencilerinin Geometrik Düşünme Düzeylerine Ait Betimsel İstatistik Sonuçları

\begin{tabular}{lcc}
\hline Geometrik Düşünme Düzeyleri & $\mathbf{N}$ & $\mathbf{\%}$ \\
\hline 0. düzey & 26 & 5.1 \\
1.düzey & 238 & 47.1 \\
2.düzey & 164 & 32.5 \\
3.düzey & 58 & 11.5 \\
4.düzey & 19 & 3.8 \\
Toplam & 505 & 100.0 \\
\hline
\end{tabular}

Ortaokul öğrencilerinin geometrik düşünme testi ağırlıklı puanları analiz edilmiş ve bu puanlara ait betimsel istatistikler Tablo 5'te verilmiştir. Tablo 5'teki bulgulara göre, öğrencilerin geometrik düşünme düzey testi ağırlıklı puanlarının ortalamasının 3.70 olduğu görülmektedir. Bu ortalama dikkate alındığında öğrencilerin geometrik düşünme düzeylerinin 2. seviyeye denk geldiği ifade edilebilir. 
Tablo 5. Ortaokul Öğrencilerinin Geometrik Düşünme Düzey Testi Ağırlıklı Puanlarına İlişkin Betimsel İstatistikler

\begin{tabular}{llll}
\hline Değişken & $\mathbf{N}$ & $\overline{\mathrm{X}}$ & $\mathbf{S S}$ \\
\hline Geometrik düşünme düzeyi ağırlıklı puan & 505 & 3.70 & 3.63 \\
\hline
\end{tabular}

Ortaokul öğrencilerinin geometrik düşünme düzey testi ağırlıklı puanları arasında öğrenim gördükleri sınıf düzeyine göre istatistiksel açıdan anlamlı bir fark olup olmadığını belirlemek amacıyla yapılan t-testi sonucunda Levene testine göre grupların dağılımının homojen olmadığı $(\mathrm{p}<.05)$ görülmüştür. Sınıf düzeyine göre geometrik düşünme düzey testi ağırlıklı puanları arasında anlamlı bir fark olup olmadığını belirlemek için Mann-Whitney U testi yapılmıştır. U-Testi sonuçları Tablo 6'da verilmiştir. Tablo 6'da görüldüğü gibi, öğrencilerin geometrik düşünme düzey testi ağırlıklı puanları arasında sınıf değişkenine göre istatistiksel olarak anlamlı bir fark bulunmuştur, $U=26473.50 ; \mathrm{p}<.05$. Sıra ortalamaları dikkate alındığında bu farkın sekizinci sınıfta öğrenim gören öğrencilerin lehine olduğu görülmektedir.

Tablo 6. Ortaokul Öğrencilerinin Geometrik Düşünme Düzey Testi Ağırlıklı Puanlarının Sınıf Düzeyine Göre U-Testi Sonuçları

\begin{tabular}{lllllll}
\hline Bağımlı Değişken & \multirow{2}{*}{ Sınıf } & N & Sıra Ort. & Sıra Top. & U & p \\
\hline Geometrik Düşünme & 7. sınıf & 241 & 230.85 & 55634.50 & 26473.50 & $.001^{*}$ \\
& 8. sınıf & 264 & 273.22 & 72130.50 & & \\
\hline
\end{tabular}

$* \mathrm{p}<.05$

Ortaokul öğrencilerinin anne eğitim düzeylerine göre, geometrik düşünme düzey testi ağırlıklı puanları arasında istatistiksel açıdan anlamlı bir fark olup olmadığını belirlemek amacıyla yapılan ANOVA testi sonucunda Levene testine göre grupların dağılımının homojen olmadığı $(p<.05)$ görüldüğünden dolayı analize Kruskal-Wallis $H$ testi ile devam edilmiştir. Yapılan analize ilişkin bulgular Tablo 7'de verilmiştir. Tablo 7'de görüldüğü gibi, öğrencilerin geometrik düşünme düzey testi ağırlıklı puanlarının anne eğitim durumuna göre anlamlı bir fark gösterip göstermediğini belirlemek amacıyla yapılan Kruskal-Wallis $\mathrm{H}$ testi sonucunda anne eğitim düzeyi gruplarının sıra ortalamaları arasındaki farkın istatistiksel olarak anlamlı olduğu belirlenmiştir, $\mathrm{x}^{2}=22.583 ; \mathrm{p}<.05$. Anlamlı farklılığın hangi gruplardan kaynaklandığını belirlemek amacıyla grupların ikili kombinasyonları üzerinden MannWhitney $U$ testi yapılmıştır. Yapılan testlerin sonucunda $5>1,5>2,5>3,5>4,3>1$ ve $4>1$ grupları arasında anlamlı farklılık olduğu tespit edilmiştir. Anlamlı farkın bu altı durumda anne eğitim düzeyi yüksek olan öğrencilerin lehine olduğu görülmüsstür. 
Tablo 7. Ortaokul Öğrencilerinin Geometrik Düşünme Düzey Testi Ağırlıklı Puanlarının Anne Eğitim Durumuna Göre H-Testi Sonuçları

\begin{tabular}{llcccccc}
\hline $\begin{array}{l}\text { Bağımlı } \\
\text { Değişken }\end{array}$ & $\begin{array}{l}\text { Anne Eğitim } \\
\text { Düzeyi }\end{array}$ & N & $\begin{array}{r}\text { Sıra } \\
\text { Ort. }\end{array}$ & Sd & $\mathbf{X}^{\mathbf{2}}$ & p & Fark \\
\hline Geometrik & (1)Okumaz- & 40 & 198.39 & 4 & 22.583 & $.000^{*}$ & $5>1,5>2$, \\
Düşünme & yazmaz & 163 & 240.71 & & & & $5>3,5>4$ \\
& (2)i்lkokul & 155 & 253.49 & & & & $3>1,4>1$ \\
& (3)Ortaokul & 86 & 251.25 & & & & \\
& (4)Lise & 61 & 322.87 & & & & \\
& (5)Üniversite & & & & & & \\
\hline
\end{tabular}

$* \mathrm{p}<.05$

Ortaokul öğrencilerinin geometrik düşünme düzey testi ağırlıklı puanları arasında baba eğitim durumu açısından istatistiksel olarak anlamlı bir fark olup olmadığını belirlemek amacıyla yapılan ANOVA testi sonucunda Levene testine göre grupların dağılımının homojen olmadığı $(\mathrm{p}<.05)$ görüldüğünden dolayı Kruskal-Wallis $\mathrm{H}$ testi ile analiz edilmiştir. Analiz sonuçları Tablo 8'de verilmiştir. Tablo 8'de görüldüğü gibi, öğrencilerin geometrik düşünme düzey testi ağırlıklı puanlarının baba eğitim durumuna göre anlamlı bir fark gösterip göstermediğini belirlemek amacıyla yapılan Kruskal-Wallis H testi sonucunda baba eğitim düzeyi gruplarının sıra ortalamaları arasındaki farkın istatistiksel olarak anlamlı olduğu belirlenmiştir, $\mathrm{x}^{2}=40.283, \mathrm{p}<.05$. Anlamlı farklılı̆̆ı hangi gruplardan kaynaklandığını belirlemek amacıyla grupların ikili kombinasyonları üzerinden MannWhitney U testi yapılmıştır. Yapılan testlerin sonucunda, anlamlı farkın baba eğitim durumu yüksek olan öğrencilerin lehine olduğu görülmektedir. $\mathrm{Bu}$ bulguların yanında, ortaokul öğrencilerinin geometrik düşünme düzey testi ağırlıklı puanlarının cinsiyet değişkeni $[\mathrm{t}(503)=0.339 ; \mathrm{p}>$.05] ve okul öncesi eğitim alma durumlarına [t(503)=0,870; $>$ > .05] göre anlamlı bir fark göstermediği saptanmıştır.

Tablo 8. Ortaokul Öğrencilerinin Geometrik Düşünme Düzey Testi Ağırlıklı Puanlarının Baba Eğitim Durumuna Göre H-Testi Sonuçları

\begin{tabular}{|c|c|c|c|c|c|c|c|}
\hline $\begin{array}{l}\text { Bağımlı } \\
\text { Değişken }\end{array}$ & $\begin{array}{l}\text { Baba Ĕ̆itim } \\
\text { Düzeyi }\end{array}$ & $\mathbf{N}$ & $\begin{array}{l}\text { Sira } \\
\text { Ort. }\end{array}$ & Sd & $\mathbf{X}^{2}$ & $\mathbf{p}$ & Fark \\
\hline \multirow{5}{*}{$\begin{array}{l}\text { Geometrik } \\
\text { Düşünme }\end{array}$} & (1)Okumaz- & 124 & 209.43 & 3 & 40.283 & $.000 *$ & $4>1$, \\
\hline & yazmaz ve ilkokul & & & & & & $4>2$, \\
\hline & (2)Ortaokul & 126 & 228.27 & & & & $4>3$ \\
\hline & (3)Lise & 139 & 261.38 & & & & $3>1$ \\
\hline & (4)Üniversite & 116 & 316.40 & & & & \\
\hline
\end{tabular}

$* \mathrm{p}<.05$ 
Ortaokul öğrencilerinin geometriye yönelik öz-yeterlik inançlarına ilişkin betimsel istatistikler Tablo 9'da verilmiştir. Tablo 9'da görüldüğü gibi, öğrencilerin geometriye yönelik öz-yeterlik inançları alt boyutlar ve toplam puan bakımından ortalamanın üzerindedir.

Tablo 9. Ortaokul Yedinci ve Sekizinci Sınıf Öğrencilerinin Geometriye Yönelik Öz-Yeterlik İnançlarına

\begin{tabular}{lccccc}
\multicolumn{7}{c}{ Betimsel İstatistikler } \\
\hline Alt Boyutlar & N & Min. & Max. & $\overline{\mathrm{x}}$ & SS \\
\hline $\begin{array}{l}\text { Geometri bilgisini } \\
\text { kullanma }\end{array}$ & 505 & 6 & 30 & 19.92 & 5.06 \\
$\begin{array}{l}\text { Olumlu-olumsuz öz } \\
\text { yeterlik }\end{array}$ & 505 & 25 & 95 & 67.45 & 13.03 \\
$\begin{array}{l}\text { Geometriye yönelik öz- } \\
\text { yeterlik inançları toplam }\end{array}$ & 505 & 35 & 125 & 87.50 & 16.86 \\
\hline
\end{tabular}

Ortaokul öğrencilerinin sınıf değişkenine göre geometriye yönelik öz-yeterlik inançlarına ait bulgular Tablo $10^{\prime}$ da verilmiştir. Tablo $10^{\prime}$ da görüldüğü gibi öğrencilerin geometriye yönelik özyeterlik inançlarının sınıf değişkeni açısından karşılaştırılmasına ilişkin bağımsız gruplar t-testi sonucunda ölçeğin "geometri bilgisini kullanma" alt boyutunda yedinci sınıf öğrencileri lehine anlamlı bir fark olduğu görülmektedir, $\mathrm{t}(503)=2.928 ; \mathrm{p}<.05$. Etki büyüklükleri dikkate alındığında, "geometri bilgisini kullanma" öz-yeterlik inancında gözlenen varyansın \%1 oranında sınıf değişkenine bağlı olduğu düşünülebilir. Sınıf değişkeni “geometri bilgisini kullanma” öz-yeterlik inancını düşük düzeyde etkilemektedir. Bunların yanı sıra, öğrencilerin geometriye yönelik öz-yeterlik inancının "olumluolumsuz öz-yeterlik inancı" alt boyutu puanları [t(503)=-1.246; $>$.05] arasında ve "geometriye yönelik öz-yeterlik inançları toplam puanları" [U=29502.50; $p>$.05.] arasında sınıf değişkeni açısından anlamlı bir fark bulunmamaktadır.

Tablo 10. Ortaokul Öğrencilerinin Geometriye Yönelik Öz-Yeterlik İnançlarının Sınıf Değişkenine Göre T-Testi

\begin{tabular}{lcccccccc}
\hline Alt Boyut & Sinıf & $\mathbf{N}$ & $\overline{\mathrm{x}}$ & SS & sd & $\mathbf{t}$ & $\mathbf{p}$ & $\boldsymbol{\mu}$ \\
\hline Geometri bilgisini & 7.Sinıf & 241 & 20.60 & 5.15 & 503 & 2.928 & $.004^{*}$ & .01 \\
kullanma & 8.Sinıf & 264 & 19.29 & 4.89 & & & & \\
\hline
\end{tabular}

$* \mathrm{p}<.05$

Ortaokul öğrencilerinin okul öncesi eğitim alma durumuna göre geometriye yönelik öz-yeterlik inançlarına ait bulgular Tablo 11'de verilmiştir. Tablo 11'de görüldüğü gibi, öğrencilerin geometriye yönelik öz-yeterlik inançlarının okul öncesi eğitim durumlarına göre karşıllaştırılmasına ilişkin bağımsız gruplar t-testi sonucunda, "geometriye yönelik öz-yeterlik inanc1 toplam puanı" [t(503)=2.022; $<<.05]$ ve "olumlu-olumsuz öz-yeterlik inancı" alt boyutunda [t (503)=2.056; $\mathrm{p}<.05]$ okul öncesi eğitim alan öğrenciler lehine anlamlı bir fark olduğu görülmektedir. Etki büyüklükleri dikkate alındığında, "geometriye yönelik öz-yeterlik inancı toplam puanı" ve "olumlu-olumsuz öz-yeterlik" inanc1 alt boyutunda gözlenen varyansın \%1 oranında okul öncesi eğitim alma durumuna bağlı olduğu düşünülebilir. Okul öncesi eğitim durumu, "geometriye yönelik öz-yeterlik inancı toplam puanını” ve 40 
"olumlu-olumsuz öz-yeterlik" inancını düşük düzeyde etkilemektedir. Bunların yanı sıra, "geometri bilgisini kullanma" inancının okul öncesi eğitim durumuna göre değişmediği saptanmıştır $[\mathrm{t}(503)=1.440 ; \mathrm{p}>.05]$.

Tablo 11. Ortaokul Öğrencilerinin Geometriye Yönelik Öz-Yeterlik İnançlarının Okul Öncesi Eğitim Alma

\begin{tabular}{|c|c|c|c|c|c|c|c|c|}
\hline \multicolumn{9}{|c|}{ Durumuna Göre T-Testi Sonuçları } \\
\hline $\begin{array}{l}\text { Alt } \\
\text { Boyutlar }\end{array}$ & $\begin{array}{l}\text { Okul } \\
\text { öncesi } \\
\text { eğitim } \\
\text { alma }\end{array}$ & $\mathbf{N}$ & $\overline{\mathrm{x}}$ & SS & sd & $\mathbf{t}$ & $\mathbf{p}$ & $\mu$ \\
\hline $\begin{array}{l}\text { Olumlu- } \\
\text { olumsuz öz- } \\
\text { yeterlik } \\
\text { inanc1 }\end{array}$ & $\begin{array}{l}\text { Evet } \\
\text { Hayır }\end{array}$ & $\begin{array}{l}262 \\
243\end{array}$ & $\begin{array}{l}68.72 \\
66.34\end{array}$ & $\begin{array}{l}13.20 \\
12.76\end{array}$ & 503 & 2.05 & $.040^{*}$ & .01 \\
\hline $\begin{array}{l}\text { Geometriye } \\
\text { yönelik öz- } \\
\text { yeterlik } \\
\text { toplam }\end{array}$ & $\begin{array}{l}\text { Evet } \\
\text { Hayır }\end{array}$ & $\begin{array}{l}262 \\
243\end{array}$ & $\begin{array}{l}88.95 \\
85.93\end{array}$ & $\begin{array}{l}17.15 \\
16.43\end{array}$ & 503 & 2.02 & $.044^{*}$ & .01 \\
\hline
\end{tabular}

Ortaokul öğrencilerinin anne eğitim durumlarına göre geometriye yönelik öz-yeterlik inançlarına ait betimsel istatistikler Tablo 12'de verilmiştir. Tablo 12'de görüldüğü gibi anne eğitim durumu yüksek olan öğrencilerin geometriye yönelik öz-yeterlik inançlarının da yüksek olduğu görülmektedir.

Ortaokul öğrencilerinin anne eğitim durumlarına göre geometriye yönelik öz-yeterlik inançlarına ait ANOVA sonuçları Tablo 13'te verilmiştir. Tablo 13'te görüldüğü gibi, öğrencilerinin anne eğitim durumlarına göre "olumlu-olumsuz öz-yeterlik" inancı alt boyutunda anlamlı bir fark bulunmuştur $[F(4,500)=3.19 ; p<.05]$. Anlamlı farkın hangi gruplar arasında olduğunu bulmak amaciyla yapılan LSD testi sonuçlarına göre, anne eğitim durumu üniversite $(\overline{\mathrm{x}}=72.70)$ olan öğrenciler ile anne eğitim durumu; okumaz-yazmaz ( $\overline{\mathrm{x}}=64.47$ ), ilkokul ( $\overline{\mathrm{x}}=67.06$ ) ve ortaokul ( $\overline{\mathrm{x}}=66.04$ ) olan öğrenciler arasında anne eğitim durumu üniversite olan öğrenciler lehine anlamlı bir fark olduğu görülmüştür. Etki büyüklükleri dikkate alındığında, "olumlu-olumsuz öz-yeterlik” inancı puanlarında gözlenen varyansın \%3 oranında anne eğitim durumuna bağlı olduğu düşünülebilir. Anne eğitim durumu öğrencilerin “olumlu-olumsuz öz-yeterlik” inancını düşük düzeyde etkilemektedir.

Tablo 13'de görüldüğü gibi, öğrencilerin "geometriye yönelik öz-yeterlik inançları toplam puanları" arasında anne eğitim durumları bakımından anlamlı bir fark olduğu görülmüştür $[\mathrm{F}(4,500)=2.99 ; \mathrm{p}<.05]$. Farkın hangi gruplar arasında olduğunu tespit etmek amacıyla yapılan LSD testi sonuçlarına göre, anne eğitim durumu üniversite ( $\overline{\mathrm{X}}=93.67)$ olan öğrenciler ile anne eğitim durumu ortaokul ( $\bar{x}=86.16$ ), ilkokul ( $\bar{x}=86.95$ ) ve okumaz-yazmaz ( $\bar{x}=83.55$ ) olan öğrenciler arasında anne eğitim durumu üniversite olan öğrenciler lehine anlamlı bir fark bulunmuştur. Etki büyüklükleri dikkate 
alındığında, geometriye yönelik öz-yeterlik inançları toplam puanlarında gözlenen varyansın \%2 oranında anne eğitim durumuna bağlı olduğu düşünülebilir. Anne eğitim durumu öğrencilerin geometriye yönelik öz-yeterlik inançları toplam puanını düşük düzeyde etkilemektedir. Bunların yanı sıra, anne eğitim durumuna göre "geometri bilgisini kullanma" alt boyutunda anlamlı bir fark olmadığı saptanmıştır, $F(4,500)=1.328 ; \mathrm{p}>.05$.

Tablo 12. Ortaokul Öğrencilerinin Geometriye Yönelik Öz-Yeterlik İnançlarının Anne Eğitim Durumlarına Ait Betimsel İstatistikler

\begin{tabular}{llccc}
\hline Boyutlar & $\begin{array}{l}\text { Anne Eğitim } \\
\text { Durumu }\end{array}$ & N & $\overline{\mathrm{X}}$ & SS \\
\hline Olumlu- & Okumaz-Yazmaz & 40 & 64.47 & 10.58 \\
Olumsuz öz- & Orlkokul & 163 & 67.06 & 12.13 \\
yeterlik & Lise & 155 & 66.04 & 12.84 \\
inanc1 & Üniversite & 86 & 69.12 & 13.92 \\
& 61 & 72.70 & 14.69 \\
Geometriye & Okumaz-Yazmaz & 40 & 83.55 & 14.51 \\
yönelik öz- & Ortkokul & 163 & 86.95 & 15.62 \\
yeterlik & Lise & 155 & 86.16 & 16.62 \\
toplam & Üniversite & 86 & 88.41 & 18.01 \\
& & 61 & 93.67 & 19.17 \\
\hline
\end{tabular}

Tablo 13. Ortaokul Öğrencilerinin Geometriye Yönelik Öz-Yeterlik İnançlarının Anne Eğitim Durumuna Göre

\begin{tabular}{|c|c|c|c|c|c|c|c|c|}
\hline $\begin{array}{l}\text { Alt } \\
\text { Boyutlar }\end{array}$ & VK & KT & sd & KO & $\mathbf{F}$ & $\mathbf{p}$ & Fark & $\mu$ \\
\hline \multirow{4}{*}{$\begin{array}{l}\text { Olumlu- } \\
\text { olumsuz öz- } \\
\text { yeterlik } \\
\text { inanc1 }\end{array}$} & GA & 2601.8 & 4 & 650.4 & \multirow[t]{4}{*}{3.195} & \multirow[t]{4}{*}{ 004* } & $5>1$ & \multirow[t]{4}{*}{.03} \\
\hline & Gİ & 83069.2 & 500 & 166.1 & & & $5>2$ & \\
\hline & & & & & & & $5>3$ & \\
\hline & Top. & 85671.0 & 504 & & & & & \\
\hline \multirow{4}{*}{$\begin{array}{l}\text { Geometriye } \\
\text { yönelik öz- } \\
\text { yeterlik } \\
\text { toplam }\end{array}$} & GA & 3347.4 & 4 & 836.8 & \multirow[t]{4}{*}{2.99} & \multirow[t]{4}{*}{$.019 *$} & $5>1$ & \multirow[t]{4}{*}{.02} \\
\hline & GA & 139960.8 & 500 & 279.9 & & & $5>2$ & \\
\hline & & & & & & & $5>3$ & \\
\hline & Top. & 143308.2 & 504 & & & & & \\
\hline
\end{tabular}

$* \mathrm{p}<.05$

Ortaokul öğrencilerin "geometriye yönelik öz-yeterlik inançlarının toplam puanı" ve "olumluolumsuz öz-yeterlik inancı" açısından baba eğitim durumu değişkenine göre yapılan ANOVA testi sonucunda grupların dağılımının homojen olmadığ $1(\mathrm{p}<.05)$ belirlendiğinden dolayı Kruskal-Wallis H testi tercih edilmiş ve bulguları Tablo 14'te verilmiştir. Tablo 14'te görüldüğg̈ gibi, baba eğitim durumu değişkenine göre, öğrencilerin "geometriye yönelik öz-yeterlik inançları toplam puanları” ile "olumluolumsuz öz-yeterlik" inanç puanları arasında anlamlı bir fark olduğu görülmektedir $(\mathrm{p}<.05)$. Anlamlı farkın hangi gruplar arasında olduğu incelendiğinde bu farkın, hem geometriye yönelik öz-yeterlik inançları toplam puanı hem de "olumlu-olumsuz öz-yeterlik" inancı alt boyutunda baba eğitim durumu üniversite olan öğrencilerle baba eğitim durumu lise, ortaokul ve ilkokul-okumaz-yazmaz olan öğrenciler arasında olduğu görülmektedir. Her iki durumda da farkın baba eğitim durumu üniversite olan öğrenciler lehine olduğu saptanmıştır. Bunların yanı sıra, öğrencilerin baba eğitim durumlarına 
göre "geometri bilgisini kullanma" inancı alt boyutunda anlamlı bir fark olmadığı belirlenmiştir $[F(3,501)=1.626 ; \mathrm{p}>.05]$.

Tablo 14. Ortaokul Öğrencilerinin Geometriye Yönelik Öz-Yeterlik İnançlarının Baba Eğitim Durumuna Göre

\begin{tabular}{|c|c|c|c|c|c|c|c|}
\hline \multicolumn{8}{|c|}{ Kruskal-Wallis H Testi Sonuçları } \\
\hline $\begin{array}{l}\text { Alt } \\
\text { Boyutlar }\end{array}$ & $\begin{array}{l}\text { Baba Eğitim } \\
\text { Düzeyi }\end{array}$ & $\mathbf{N}$ & $\begin{array}{l}\text { Sira } \\
\text { Ort. }\end{array}$ & Sd & $\mathbf{X}^{2}$ & $\mathbf{p}$ & Fark \\
\hline $\begin{array}{l}\text { Olumlu- } \\
\text { olumsuz } \\
\text { öz-yeterlik } \\
\text { inanc1 }\end{array}$ & $\begin{array}{l}\text { (1)İlkokul ve } \\
\text { okumaz-yazmaz } \\
\text { (2)Ortaokul } \\
\text { (3)Lise } \\
\text { (4)Üniversite }\end{array}$ & $\begin{array}{l}124 \\
126 \\
139 \\
116 \\
\end{array}$ & $\begin{array}{l}228.83 \\
\\
233.74 \\
256.97 \\
294.99 \\
\end{array}$ & 3 & 15.31 & $.002 *$ & $\begin{array}{l}4>1, \\
4>2, \\
4>3\end{array}$ \\
\hline $\begin{array}{l}\text { Geometriye } \\
\text { yönelik öz- } \\
\text { yeterlik } \\
\text { toplam }\end{array}$ & $\begin{array}{l}\text { (1)İlkokul ve } \\
\text { okumaz-yazmaz } \\
\text { (2)Ortaokul } \\
\text { (3)Lise } \\
\text { (4)Üniversite }\end{array}$ & $\begin{array}{l}124 \\
126 \\
139 \\
116\end{array}$ & $\begin{array}{l}231.19 \\
\\
238.48 \\
252.53 \\
292.66 \\
\end{array}$ & 3 & 12.59 & $.006^{*}$ & $\begin{array}{l}4>1, \\
4>2, \\
4>3\end{array}$ \\
\hline
\end{tabular}

$* \mathrm{p}<.05$

Bu bulguların yanında, ortaokul öğrencilerinin cinsiyet değişkenine göre, geometriye yönelik özyeterlik inançlarının "geometriye yönelik öz-yeterlik inancı toplam puanı" [t(503) $=-.091 ; \mathrm{p}>.05]$ ile "olumlu-olumsuz öz-yeterlik inancı" $[\mathrm{t}(503)=.459 ; \mathrm{p}>.05]$ ve geometri bilgisini kullanma [U=29949.50; $p>.05]$ alt boyutlarında anlamlı bir fark olmadığı tespit edilmiştir.

Ortaokul öğrencilerinin geometrik düşünme düzey testi ağırlıklı puanları ile geometriye yönelik öz-yeterlik inançları arasındaki Pearson korelasyon katsayıları Tablo 15'te verilmiştir. Tablo 15'te görüldüğü gibi, öğrencilerin "geometrik düşünme düzey testi ağırlıklı puanları" ile "geometriye yönelik öz-yeterlik inançları toplam puanı" ( $(\mathrm{r}=.164, \mathrm{p}<.05)$ ve "olumlu-olumsuz öz-yeterlik inançları" ( $\mathrm{r}=.181$, $\mathrm{p}<.05)$ arasında düşük düzeyde pozitif yönlü anlamlı bir ilişki olduğu görülmektedir. Bunun yanı sıra, öğrencilerin "geometrik düşünme düzey testi ağırlıklı puanları" ile "geometri bilgisini kullanma" inançları arasında anlamlı bir ilişkinin olmadığı tespit edilmiştir ( $p>.05)$.

Tablo 15. Öğrencilerin Geometrik Düşünme Düzey Testi Ağıllıklı Puanları İle Geometriye Yönelik Öz-Yeterlik İnançları Arasındaki Pearson Korelâsyon Katsayıları

\begin{tabular}{llcccc} 
& \multicolumn{4}{c}{ İnançları Arasındaki Pearson Korelâsyon Katsayıları } \\
\cline { 3 - 6 } & & $\begin{array}{c}\text { Geometriye } \\
\text { yönelik öz- } \\
\text { yeterlik inançlar } \\
\text { toplam }\end{array}$ & $\begin{array}{c}\text { Geometri } \\
\text { bilgisini } \\
\text { kullanma }\end{array}$ & $\begin{array}{c}\text { Olumlu- } \\
\text { olumsuz } \\
\text { olz-yeterlik }\end{array}$ \\
\cline { 3 - 6 } & Geometrik & $\mathrm{N}$ & 505 & 505 & 505 \\
& düşünme & $\mathrm{r}$ & $.164 *$ & .081 & $.181^{*}$ \\
& $\mathrm{p}$ & .000 & .070 & .000 \\
\hline $\mathrm{p}<.05$ & & \multicolumn{4}{c}{}
\end{tabular}

\section{Sonuç, Tartışma ve Öneriler}

Araştırmada elde edilen sonuçlara göre, öğrencilerin büyük çoğunluğunun (\% 84.7) geometrik düşünme düzeylerinin 2.düzey ve altında yer aldıkları sonucuna ulaşılmıştır. Ortaokul öğrencilerinin 
çoğunlukla 3. düzeyde olmas1 gerektiği (Altun, 2015b) düşünüldüğünde örneklemdeki öğrencilerin geometrik düşünme becerisi bakımından olması gereken düzeyin altında yer aldıkları görülmektedir. Van Hiele geometrik düşünme kuramı öğrencilerin geometrik düşünme gelişiminin hiyerarşik beş basamaktan oluştuğunu ve öğrencilerin bu basamakları sırasıyla geçtiğini varsaymaktadır. Bir düzeydeki öğrenme eksiklikleri öğrencilerin bir sonraki düzeydeki öğrenmelerini zorlaştırmaktadır (Van Hiele, 1986; 1999). Böyle bir sonucun ortaya çıkmasında öğrencilerin önceki düzeylerdeki öğrenme eksiklikleri etkili olmuş olabilir. Bu araştırmanın sonuçlarına benzer şekilde Usiskin (1982), Cantürk-Günhan (2006), Fidan (2009), Y1lmaz (2011), Alaylı (2012), Oral ve diğerleri (2013), Gül (2014) ve Karakarçayıldız (2016) yaptıkları çalışmalarda ortaokul öğrencilerinin geometrik düşünme düzeylerinin olması gereken düzeyin altında yer aldıkları sonucuna ulaşmışlardır.

Araştırmada cinsiyet değişkeninin ortaokul öğrencilerinin geometrik düşünme düzey testi ağırlıklı puanlarını etkilemediği belirlenmiştir. Böyle bir sonucun ortaya çıkmasında, ortaokul döneminde cinsiyete ait biyolojik ve sosyolojik özelliklerin ayırt edici rolünün etkili olmadığ1 düşünülebilir. Araştırmanın sonucuna benzer şekilde Oflaz (2010), Gül (2014) ve Karakarçayıldız (2016) öğrencilerin geometrik düşünme becerileri ile cinsiyet değişkeni arasında anlamlı bir ilişki belirlememişlerdir. $\mathrm{Bu}$ araştırmaların aksine öğrencilerin geometrik düşünme düzeyleri ile cinsiyet arasında anlamlı bir ilişki olduğu sonucuna varan çalışmalardan Duatepe (2000) erkek öğrenciler lehine, Fidan (2009) ise kız öğrenciler lehine anlamlı bir fark belirlemişlerdir.

Araştırmada varılan diğer bir sonuca göre, sekizinci sınıf öğrencilerinin geometrik düşünme düzey testi ağırlıklı puanları yedinci sınıf öğrencilerinin puanlarından daha yüksektir. Sekizinci sınıf öğrencilerinin yedinci sınıf öğrencilerine göre daha fazla matematik dersi almış olmaları böyle bir sonucun ortaya çıkmasında etkili olmuş olabilir. Çanakçı (2008) öğrencilerin matematik başarılarını karşılaştırdığı araştırmasında sekizinci sınıf öğrencilerinin altı ve yedinci sınıf öğrencilerinden daha başarılı olduğu sonucuna varmıştır. Bu araştırmanın aksine Oflaz (2010) öğretmen adayları ile yaptığı araştırmada birinci sınıfta öğrenim gören öğretmen adayları ile dördüncü sınıfta öğrenim gören öğretmen adaylarının geometrik düşünme düzeylerinin anlamlı bir fark göstermediğini belirlemiştir.

Araştırmada okul öncesi eğitim alma durumunun ortaokul öğrencilerinin geometrik düşünme düzey testi ağırlıklı puanlarını etkilemediği belirlenmiştir. Araştırmaya katılan ortaokul öğrencilerinden okul öncesi eğitim alanların çeşitli geometrik şekillerle ve geometrik düşünmeyi geliştiren materyallerle yeterince ya da doğru biçimde etkileşimde bulunmamaları böyle bir sonucun ortaya çımasında etkili olmuş olabilir. Araştırmanın sonuçlarına benzer olarak Karakarçayıldız (2016) yedinci sınıf öğrencilerinin geometrik düşünme düzeylerinin okul öncesi eğitim durumuna göre farklılaşmadığını belirlemiştir. Fakat Fidan (2009) beşinci sınıf öğrencileri ile yaptığı çalışmada okul öncesi eğitim alan 
öğrencilerin geometrik düşünme düzeylerinin okul öncesi eğitim almayan öğrencilerin geometrik düşünme düzeylerinden daha yüksek olduğu sonucuna varmıştır.

Araştırmadan elde edilen sonuçlara göre öğrencilerin anne eğitim seviyesi yükseldikçe geometrik düşünme becerileri de yükselmektedir. Eğitim durumu yüksek olan annelerin, çocuklarının akademik anlamda gelişimini daha çok destekleyebilme olasılığından dolayı böyle bir sonuç çıkmış olabilir. Araştırmanın sonuçlarına benzer olarak Fidan (2009) beşinci sınıf öğrencileri ile yaptığı araştırmada anne eğitim düzeyi yükseldikçe öğrencilerin geometrik düşünme düzeylerinin de yükseldiğini tespit etmiştir. Hortasçu (1995), Çanakçı (2009) ve Gürsakal (2012) öğrencilerin anne eğitim düzeyi yükseldikçe matematik başarılarının da arttığı sonucuna varmışlardır. Bu araştırmaların aksine Karakarçayıldız (2016) anne eğitim durumu ile öğrencilerin geometrik düşünme düzeyleri arasında anlamlı bir ilişki olmadığını belirlemiştir.

Araştırmada öğrencilerin baba eğitim durumu yükseldikçe geometrik düşünme becerilerinin de yükseldiği sonucuna varılmıştır. Araştırmanın sonuçlarına benzer olarak Fidan (2009) öğrencilerin baba eğitim düzeyi yükseldikçe geometrik düşünme düzeylerinin de yükseldiğini bulmuştur. Benzer biçimde Çanakçı (2009) ve Gürsakal (2012) öğrencilerin baba eğitim düzeyi arttıkça matematik başarılarının da arttı̆̆ 1 sonucuna varmıştır. Bu araştırmaların aksine Karakarçayıldız (2016) baba eğitim durumu ile öğrencilerin geometrik düşünme düzeyleri arasında anlamlı bir ilişki olmadığını belirlemiştir.

Araştırmada, öğrencilerin geometriye yönelik öz-yeterlik inanç puanlarının aritmetik ortalamanın üzerinde olduğu sonucuna ulaşılmıştır. Geometrinin şekillerin özelliklerini inceleyen bir bilim dalı olması, günlük yaşamda kullanılan çoğu eşyanın geometrik özellikler içermesi, öğrencilerin geometri bilgilerini günlük yaşama aktarmasının daha kolay olması ve matematiğin alt dalları içerisinde en somut olanının geometri olması, öğrencilerin geometriye yönelik öz-yeterlik inançlarının ortalamanın üzerinde olmasında etkili olmuş olabilir. Erkek ve Işıksal-Bostan (2015) ise yaptıkları araştırmada sekizinci sınıf öğrencilerinin geometriye yönelik öz-yeterlik inançlarının orta düzeyde olduğunu belirlemişlerdir. Yenilmez ve Uygan (2010) ise yedinci sınıf öğrencilerinin geometriye yönelik öz-yeterlik inançlarının yüksek düzeyde olduğunu tespit etmiştir.

Araştırmada cinsiyet değişkeninin, ortaokul öğrencilerinin hem "geometriye yönelik öz-yeterlik inançları toplam puanını" hem de "geometri bilgisini kullanma", "olumlu-olumsuz öz-yeterlik" inançlarını etkilemediği sonucuna ulaşılmıştır. Araştırmanın sonuçlarına benzer olarak Çağırgan-Gülten ve Soytürk (2013), Erdoğan ve diğerleri (2011) ve Kaba ve diğerleri (2016) cinsiyet değişkeninin öğrencilerin geometriye yönelik öz-yeterlik inançlarını etkilemediği sonucuna ulaşmışlardır. Yenilmez ve Korkmaz (2013) ise geometriye yönelik öz-yeterlik inançları ölçeğinin "olumlu öz-yeterlik inançları" ve "geometri bilgisini kullanma" alt boyutlarının cinsiyet değişkeninden etkilenmediğini, ancak erkek 
öğrencilerin “olumsuz öz-yeterlik inançlarının” kız öğrencilerin puanlarından yüksek olduğunu belirlemiştir.

Araştırmada sınıf değişkeninin, ortaokul öğrencilerinin geometriye yönelik öz-yeterlik inançları toplam puanını ve "olumlu-olumsuz öz-yeterlik" inancını etkilemediği, fakat ölçeğin "geometri bilgisini kullanma" alt boyutunda yedinci sınıf öğrencilerinin ortalamalarının daha yüksek olduğu sonucuna ulaşı1mıştır. Öğrencilerin sınıf düzeyi arttıkça matematik dersinde gördükleri konu sayısı da artmaktadır. Konuların yoğunlaşmasıyla birlikte öğrencilerde matematiğe karşı var olan önyargıları artmakta ve dolayısıyla başaramayacaklarına olan inançları da artmaktadır. Bu olumsuz inançların artması böyle bir sonucun çıkmasında etkili olmuş olabilir. Araştırmanın sonuçlarına benzer olarak Kaba ve diğerleri (2016), 5.sınıf öğrencilerinin geometriye yönelik öz-yeterlik inançlarının altı, yedi ve sekizinci sınıf öğrencilerin öz-yeterlik inançlarından daha yüksek olduğunu bulmuşlardır. Ayrıca sınıf düzeyi yükseldikçe öğrencilerin geometriye yönelik öz-yeterlik inanç puanlarının düştüğü sonucuna varmışlardır. Yenilmez ve Korkmaz (2013) öğrencilerin geometriye yönelik öz-yeterlik inançlarının sınıf değişkenine göre "olumlu öz-yeterlik inançları" ve "olumsuz öz-yeterli inançları” alt boyutlarında anlamlı bir fark yokken, "geometri bilgisini kullanma" alt boyutunda altı ile sekizinci sınıf öğrencileri arasında altıncı sınıf lehine anlamlı bir fark bulmuştur.

Araştırmada okul öncesi eğitim alan öğrencilerin, "geometriye yönelik öz-yeterlik inançlarının toplam puanlarının" ve "olumlu-olumsuz öz-yeterlik inançlarının" daha yüksek olduğu sonucuna ulaşılmıştır. Van Hiele (1999) geometrinin çocuklar için oyunla başladığını ifade etmiştir. Okul öncesi eğitim alan öğrenciler programlarında yer alan matematik etkinliklerini görsel materyallerle ve oyunla öğrendikleri için bu sonuca ulaşılmış olabilir. Bu araştırmanın aksine Yenilmez ve Korkmaz (2013) okul öncesi eğitim alma durumunun öğrencilerin geometriye yönelik öz-yeterlik inançlarını etkilemediğini belirlemiştir.

Araştırmada elde edilen bulgulara göre, anne eğitim durumu yükseldikçe öğrencilerin geometriye yönelik öz-yeterlik inançlarının da yükseldiği sonucuna ulaşılmıştır. Anne eğitim durumu yüksek olan öğrencilerin anneleri tarafından daha çok desteklenmeleri ve bu öğrencilerin herhangi bir başarısızlık durumunda olumsuz duygulara daha az kapılıyor olmaları böyle bir sonucun ortaya çıkmasında etkili olmuş olabilir. Araştırmanın sonuçlarına benzer şekilde Kaba ve diğerleri (2016) anne eğitim durumu yükseldikçe öğrencilerin geometriye yönelik öz-yeterlik inanç puanlarının da yükseldiği sonucuna ulaşmışlardır. Özkan (2010) anne eğitim durumunun sekizinci sınıf öğrencilerinin geometriye yönelik olumlu öz-yeterlik inançları üzerinde anlamlı bir etkisi olduğunu belirlese de bu etkinin (\%3-\%7) pratikte anlamlı olamayabileceğini ifade etmiştir.

Araştırmada elde edilen bulgulara göre, baba eğitim durumu yükseldikçe öğrencilerin geometriye yönelik öz-yeterlik inançlarının da yükseldiği sonucuna ulaşılmıştır. Baba eğitim durumu yüksek olan 
öğrenciler zihinsel ve duygusal gelişimleri bakımından babaları tarafından daha çok yardım alıyor olmaları böyle bir sonucun ortaya çıkmasında etkili olmuş olabilir. Araştırmanın sonuçlarına benzer şekilde Kaba ve diğerleri (2016) baba eğitim durumu yükseldikçe öğrencilerin geometriye yönelik özyeterlik inanç puanlarının da yükseldiği sonucuna ulaşmışlardır. Özkan (2010) baba eğitim durumunun altı ve yedinci sınıf öğrencilerinin geometriye yönelik öz-yeterlik inançları üzerinde anlamlı bir etkisi olduğunu belirlemiş, ancak bu etkinin (\%3-\%7) pratikte anlamlı olamayabileceğini ifade etmiştir.

Ortaokul öğrencilerinin "geometrik düşünme düzey testi ağırlıklı puanları" ile "geometriye yönelik öz-yeterlik inançları toplam puanı” ve "olumlu-olumsuz öz-yeterlik” inançlarının aynı yönde değişim gösterdiği sonucuna varılmıştır. Diğer bir deyişle öğrencilerin geometriye yönelik öz-yeterlik inanç puanları yükseldikçe geometrik düşünme testinden aldıkları puanların da yükselebileceği ifade edilebilir. Araştırmanın sonucuna benzer şekilde Yenilmez ve Korkmaz (2013) öğrencilerin "geometrik düşünme düzeyleri” ile "olumlu öz-yeterlik inançları" arasında pozitif yönde düşük düzeyde anlamlı bir ilişki belirlemesinin yanı sıra, bu araştırmadan farklı olarak geometrik düşünme düzeyleri ile "geometri bilgisinin kullanılması" arasında pozitif yönde düşük düzeyde anlamlı bir ilişki ortaya koymuşlardır. Kaba ve diğerleri (2016) "geometriye yönelik tutum” ile "olumsuz öz-yeterlik" inancı arasında pozitif yönde düşük düzeyde anlamlı bir ilişki olduğunu, ayrıca "geometriye yönelik tutum" ile "olumlu özyeterlik" inancı arasında pozitif yönde yüksek düzeyde anlamlı bir ilişki olduğunu belirlemişlerdir.

Araştırmanın sonuçlarına dayalı olarak uygulayıcılara ve araştırmacılara yönelik aşağıdaki öneriler ileri sürülebilir:

- Araştırmada öğrencilerin geometrik düşünme becerilerinin yeterli düzeyde olmadığı belirlendiğinden dolayı, dönem başında öğrencilerin geometrik düşünme düzeylerinin ölçülüp, olması gereken düzeyin altında yer alan öğrencilerin düzeylerini yükseltmek için ek öğretim etkinlikleri düzenlenebilir.

- Araştırmada öğrencilerin geometrik düşünme becerileri bakımından farklı düzeylerde olduğu belirlendiğinden dolayı, öğretmenlere bu düzeyleri dikkate alarak öğretim yapabilmeleri için hizmet içi eğitim verilerek Van Hiele kuramı hakkında bilgi sahibi olmaları sağlanabilir.

- Araştırmada öğrencilerin geometrik düşünme düzeylerinin düşük olduğu sonucuna varılmıştır. Başka araştırmalarda bunun neden kaynaklandığına ilişkin öğretmen görüşlerine dayalı nitel araştırmalar yapılabilir.

- Araştırmada öğrencilerinin geometri öz-yeterlik inançları ile geometrik düşünme becerileri ilişkisel tarama modeli ile incelenmiştir. İleride yapılacak araştırmalarda öğrencilerin matematik dersindeki bu davranışlarını artırmaya yönelik deneysel uygulamalar yapılabilir. 


\section{Kaynakça}

Altun, M. (2015a). Eğitim fakülteleri ve sınıf ögretmenleri için matematik ögretimi (19.Bask1). Bursa: Alfa Akademi.

Altun, M. (2015b). Illköğretim ikinci kademede (6, 7, 8. sinıflarda) matematik ögretimi (11.Bask1). Bursa: Aktüel.

Akkaya, S. Ç. (2006). Van Hiele düzeylerine göre hazırlanan etkinliklerin ilköğretim 6. slnıf öğrencilerinin tutumuna ve başarısına etkisi. Yayımlanmamış yüksek lisans tezi, Abant İzzet Baysal Üniversitesi Sosyal Bilimler Enstitüsü, Bolu.

Alaylı, F. G. (2012). Geometride şekil oluşturma ve şekli parçalarına ayırma çalışmalarında ilköğretim 6. 7. ve 8. sınıf öğrencilerinin düşünme süreçlerinin incelenmesi ve bu süreçteki düzeylerinin belirlenmesi. Yayımlanmış doktora tezi, Dokuz Eylül Üniversitesi Eğitim Bilimleri Enstitüsü, İzmir.

Aslan, D. ve Aktaş Arnas, Y. (2005). Okul öncesi dönemde geometri. Eğitim Bilim Toplum Dergisi, 3(9), 36-46.

Aşkar, P. ve Umay, A. (2001). İlköğretim matematik öğretmenliği öğrencilerinin bilgisayarla ilgili öz-yeterlik alg1s1. Hacettepe Üniversitesi Eğitim Fakültesi Dergisi, 21, 1-8.

Ayotola, A. ve Adedeji, T. (2009). The relationship between mathematics self-efficacy and achievement in mathematics. Procedia Social and Behavioral Sciences, 1, 53-57.

Baki, A. (2006). Kuramdan uygulamaya matematik eğitimi. Ankara: Harf Eğitim Yayıncılığı.

Bandura, A. (1997). Self-efficacy: the exercise of control. New York: W. H. Freeman and Company.

Başer, N. ve Cantürk-Günhan, B. (2007). Geometriye yönelik öz-yeterlik ölçeğinin geliştirilmesi, Hacettepe Üniversitesi Ĕ̆itim Fakültesi Dergisi, 33, 68-76.

Baykul, Y. (2014). Ortaokulda matematik ögretimi (17. Baskı). Ankara: Pegem Akademi.

Baykul, Y. (2016). Illkokulda matematik öğretimi (13.Baskı). Ankara: Pegem Akademi.

Büyüköztürk, Ş. (2007). Sosyal bilimler için veri analizi el kitabı (7.Baskı). Ankara: Pegem Akademi.

Büyüköztürk, Ş., Çokluk, Ö. ve Köklü, N. (2015). Sosyal bilimler için istatistik (17.Baskı). Ankara: Pegem Akademi.

Cantürk-Günhan, B. (2006). Illköğretim II. kademede matematik dersinde probleme dayalı öğrenmenin uygulanabilirliği üzerine bir araştırma. Yayımlanmamış doktora tezi, Dokuz Eylül Üniversitesi Eğitim Bilimleri Enstitüsü, İzmir.

Chen, P. ve Zimmerman, B. (2007). A cross-national comparison study on the accuracy of self-efficacy beliefs of middle-school mathematics students. The Journal of Experimental Education, 75(3), 221-244.

Clements, D. H. ve Batista, M. T. (1992). Geometry and spatial reasoning. In D. A. Grouws (Ed.), Handbook of research on mathematics teaching and learning. New York: Macmillan. 
Çağırgan-Gülten, D. ve Soytürk, İ. (2013). İlköğretim 6. sınıf öğrencilerinin geometri öz-yeterliklerinin akademik başarı not ortalamaları ile ilişkisi. Mehmet Akif Ersoy Üniversitesi Eğitim Fakültesi Dergisi, 25, 55-70.

Çanakçı, O. (2008). Matematik problemi çözme tutum ölçeğinin geliştirilmesi ve değerlendirilmesi. Yayımlanmamış doktora tezi, Marmara Üniversitesi Eğitim Bilimleri Enstitüsü, İstanbul.

Çetin, B. (2009). Yeni ilköğretim programı (2005) uygulamalarının ilköğretim 4. ve 5. sınıf öğrencilerinin öz yeterliliklerine etkisi. Pamukkale Üniversitesi Eğitim Fakültesi Dergisi, 25(1), 130-141.

Develi, H. M. ve Orbay, K. (2003). İlköğretimde niçin ve nasıl bir geometri öğretimi. Milli Eğitim Dergisi, 157.

Duatepe Paksu, A. (2016). Geometrik düşünme. E. Bingölbali, S. Arslan ve İ.Ö. Zembat (Ed.), Matematik Eğitiminde Teoriler (265-275). Ankara: Pegem Akademi.

Erdoğan, A., Baloğlu ve Kesici, S. (2011). Gender differences in geometry and mathematics achievement and selfefficacy beliefs in geometry. Eurasian Journal of Educational Research, 43, 188-205.

Erkek, Ö. ve Işıksal-Bostan, M. (2015). Uzamsal kaygı, geometri öz-yeterlik algısı ve cinsiyet değişkenlerinin geometri başarısını yordamadaki rolleri. Illköğretim Online, 14(1), 164-180.

Fidan, Y. (2009). Illköğretim 5. sinıf öğrencilerinin geometrik düşünme düzeyleri ve buluş yoluyla geometri ögretiminin ögrrencilerin geometrik düşünme düzeylerine etkisi. Yayımlanmamış doktora tezi, Dokuz Eylül Üniversitesi Eğitim Bilimleri Enstitüsü, İzmir.

Fidan, Y. ve Türnüklü, E. (2010). İlköğretim 5. sınıf öğrencilerinin geometrik düşünme düzeylerinin bazı değişkenler açısından incelenmesi. Pamukkale Üniversitesi Eğitim Fakültesi Dergisi, 27, 185-197.

Gül, B. (2014). Ortaokul 8. sınıf ögrrencilerinin üçgenler konusundaki matematiksel başarıları ile Van Hiele geometrik düşünme düzeyleri ilişkisinin incelenmesi. Yayımlanmamış yüksek lisans tezi, Gazi Üniversitesi Eğitim Bilimleri Enstitüsü, Ankara.

Gürsakal, S. (2012). PISA 2009 başarı düzeylerini etkileyen faktörlerin değerlendirilmesi. Süleyman Demirel Üniversitesi İktisadi ve İdari Bilimler Fakültesi Dergisi, 17(1), 441-452.

Güven, B. ve Karpuz, Y. (2016). Geometrik muhakeme: Bilişsel perspektifler. E. Bingölbali, S. Arslan ve İ.Ö. Zembat (Ed.), Matematik Ĕgitiminde Teoriler (245-263). Ankara: Pegem Akademi.

Halat, E. (2006). Geometri. H. Gür (Ed.), Matematik Öğretimi (271-310). İstanbul: Lisans Yayıncılık.

Hackett, G. ve Betz, N. E. (1989). An exploration of the mathematics self-efficacy/mathematics performance correspondence. Journal for Research in Mathematics Education, 20, 261-273.

Hoffer, A. (1981). Geometry is more than proof. Mathematics Teacher, 74, 11-18.

Hortaçsu, N. (1995). Parents' education levels', parents' beliefs, and child outcomes, The Journal of Genetic Psychology. 156(3), 373-383.

Idris, N. (2009). The impact of using geometers' sketchpad on malaysian students' achievement and Van Hiele geometric thinking. Journal of Mathematics Education, 2(2), 94-107.

Iş̧1ksal, M. ve Aşkar, P. (2003). İlköğretim öğrencileri için matematik ve bilgisayar öz-yeterlik algısı ölçekleri. Hacettepe Üniversitesi Eğitim Fakültesi Dergisi, 25, 109-118. 
Kaba, Y., Boğazlıyan, D. ve Daymaz, B. (2016). Ortaokul öğrencilerinin geometriye yönelik tutumları ve özyeterlikleri. The Journal of Academic Social Science Studies, 52, 335-350.

Karakarçayıldız, R. Ü. (2016). 7. sınıf öğrencilerinin geometrik düşünme düzeyleri ile çokgenleri sınıflama becerileri arasındaki ilişki. Yayımlanmamış yüksek lisans tezi, Eskişehir Osman Gazi Üniversitesi Eğitim Bilimleri Enstitüsü, Eskişehir.

Karasar, N. (2007). Bilimsel araştırma yöntemi. (17.Baskı). İstanbul: Nobel Yayın Dağıtım.

Napitipulu, B. (2004). An exploration of students' understanding and Van Hiele levels of thinking on geometric constructions. Dissertation Abstract Index, 42(2), 172A.

Oflaz, G. (2010). Geometrik düşünme seviyeleri ve zekâ alanları arasındaki ilişki. Yayımlanmamış yüksek lisans tezi, Cumhuriyet Üniversitesi Sosyal Bilimler Enstitüsü, Sivas.

Olkun, S. ve Toluk-Uçar, Z. (2006). İlköğretimde matematik ĕ̆itiminde çă̆daş yaklaşımlar. Ankara: Ekinoks.

Olkun, S. ve Toluk-Uçar, Z. (2014). Illköğretimde etkinlik temelli matematik öğretimi (6.Baskı). Ankara: Eğiten Kitap.

Oral B., İlhan M. ve Kınay, İ. (2013). 8. sınıf öğrencilerinin geometrik ve cebirsel düşünme düzeyleri arasındaki ilişkinin incelenmesi. Pamukkale Üniversitesi Ĕgitim Fakültesi Dergisi, 34, 33-46.

Özcan, B. N. (2012). İlköğretim ögrrencilerinin geometrik düşünme düzeylerinin geliştirilmesinde bilgiyi oluşturma süreçlerinin incelenmesi. Yayımlanmamış doktora tezi, Dokuz Eylül Üniversitesi Eğitim Bilimleri Enstitüsü, İzmir.

Özkan, E. (2010). Geometri öz-yeterliği, cinsiyet, sınıf seviyesi, anne-baba eğitim durumu ve geometri başarlsı arasındaki ilişkiler. Yayımlanmamış yüksek lisans tezi, Abant İzzet Baysal Üniversitesi Sosyal Bilimler Enstitüsü, Bolu.

Pusey, E. L. (2003). The Van Hiele model of reasoning in geometry: a literature review, Mathematics Education Raleigh. North Carolina State University.

Senemoğlu, N. (1997). Gelişim, öğrenme ve öğretim kuramdan uygulamaya. Ankara: Spot Matbaac1lık.

Senk, S. L. (1989). Van Hiele levels and achievement in writing geometry proofs. Journal for Research in Mathematics Education, 20(3), 309-321.

Usıskın, Z. (1982). Van Hiele levels and achievement in secondary school geometry, University of Chicago, Cognitive Development and Achievement in Secondary School Geometry (CDASSG) Project.

Uzar, F. N. (2010). İlköğretim öğrencilerinin matematik dersine yönelik öz-yeterliğini besleyen kaynakların farklı değişkenlere göre incelenmesi. Yayımlanmamış yüksek lisans tezi, Hacettepe Üniversitesi Sosyal Bilimler Enstitüsü, Ankara.

Van De Wella, J. A., Karp, K. S. ve Bay-Williams, J. M. (2013). Illkokul ve ortaokul matematiği (çev. Ed. S. Durmuş). (7.Baskı). Ankara: Nobel Akademik Yayıncılık.

Van Hiele, P. M. (1986). Structure and insight: a theory of mathematics education. Florida: Academic Pres. Inc.

Van Hiele, P. M. (1999). Developing geometric thinking through activities that begin with play, Teaching Children Mathematics, 5(6), 310-316. 
Yenilmez, K. ve Uygan, C. (2010). Yaratıcı drama yönteminin ilköğretim 7. sınıf öğrencilerinin geometriye yönelik öz-yeterlik inançlarına etkisi. Kastamonu Eğitim Dergisi, 18(3), 931-942.

Yenilmez, K. ve Korkmaz, D. (2013). İlköğretim 6, 7 ve 8. sınıf öğrencilerinin geometriye yönelik öz-yeterlikleri ile geometrik düşünme düzeyleri arasındaki ilişki, Necatibey Eğitim Fakültesi Elektronik Fen ve Matematik Ĕ̈itimi Dergisi, 7(2), 268-283.

Yıldırım, A. ve Şimşek, H. (2018). Sosyal bilimlerde nitel araştırma yöntemleri. Ankara: Seçkin Yayıncılık.

Yıldırım, S. ve Özkan, E. (2013). Geometri başarısı, geometri öz-yeterliği, ebeveyn eğitim durumu ve cinsiyet arasındaki ilişkiler, Ankara Üniversitesi Ĕgitim Bilimleri Fakültesi Dergisi, 46(2), 249-261.

Yılmaz, Ç. (2011). 6, 7 ve 8. sinıf öğrencilerinin matematik güdüsü, kaygısl, öz-yeterlik inancı ve öz kavramı ile matematik dersine yönelik tutumları arasındaki ilişkiler (Şereflikoçhisar örneği). Yüksek lisans tezi, Ankara Üniversitesi Eğitim Bilimleri Enstitüsü, Ankara.

\section{Extended Abstract}

Geometry and geometrical reasoning have provided contributions to the development of mathematics. Geometry provides the investigation of the physical world in which we live. When children learn geometry they follow a pathway similar to historical stages of the development of the geometry. According to the need of the inheritance of the gained geometical notion to the new generations, from the beginning of the 20th century to the present, many research has been made to enrich the geometry teaching and learning processes. By the help of research, the nature of the geometrical reasoning and development have been tried to be explained. The most important investigation of geometrical reasoning of children has made by Van Hieles. Dutch educators Pierre and Dina Van Hiele, have observed as some students were succesful and some were not on high school geometry and have investigated the reasons of this situation. The investigations have indicated that geometrical reasoning is five staged. The levels identify the students' ability to differentitate geometrical ideas and pathways of thinking rather than knowledge set that students must have. It has been indicated in many investigations that Turkish students' achievements are very low in both national and international examinations. It is seen that studens also slog in geometry classes in mathematics. In order to develop students' geometry achievements and positive attitudes towards mathematics, organizing the teaching process according to students level is essential. In many investigations, Van Hiele theory sits on an essential place when deciding the level of students' geometrical reasoning. In this context, the purpose of this study is investigation of students' geometrical reasoning and selfefficacies towards the geometry in terms of gender, grade level, literacy of parents and taking kindergarten education.

This is a correlational study that aims to investigate the correlation between some independent variables and geometrical reasoning skills and self efficacy beliefs towards to the geometry of middle school students. The sample is composed of total of 505 middle school students. The data of the study was collected by Van Hiele Geometrical Reasoning Leveling Test and Self-Efficacy Test Towards Geometry. The data was analysed via using independent samples t-test, ANOVA, U Test, H Test, and Pearson correlation test. 
According to the results obtained, it has found that middle school students are in the second level of the geometrical reasoning which indicates that students are not at the level that they must be. It has also found that gender and taking kindergarten education has not effected geometrical reasoning. On the contrary, it has found that by the rise of students' grade level and literacy of the parents, the geometrical reasoning skills are increased too. Besides, it has seen that students' self-efficacy beliefs towards geometry are at mid-level. It has been detected that gender variable has not effected both self-efficacy beliefs towards geometry points and "using geometrical knowledge" and "positive-negative self efficacy" beliefs. The grade level variable has not effected the total points of selfefficacy beliefs and "positive-negative self-efficacy beliefs" but 7th graders' mean scores with respect to the 8th graders has found to be higher at "using geometry knowledge" which is the lower dimension of the scale. The students' total points of self-efficacy beliefs towards geometry and "positive-negative self efficacy" beliefs have been found to be higher for students who have taken kindergarten education, but kindergarten education has not effected the beliefs of "using geometry knowledge". Total points of students' self-efficacy beliefs and "positivenegative self efficacy" beliefs has found to be higher than others in the variable of parents' literacy at the level of university graduate. On the contrary, literacy level of parents has not effected beliefs of "using geometry knowledge". Besides, when the total points of the students' self efficacy beliefs and "positive-negative selfefficacy" beliefs has increased, geometrical reasoning skills also have been increased.

In this study, because of the students' geometrical reasoning has differentiated, low leveled students could be detected at the beginning of academic year so that additional exercises may be planned to increase the students' geometrical reasoning levels. Because the students' geometrical reasoning levels have found to be low, further research may focus on the causes of this problem by the help of a quantitative study based on the teachers' opinions. 